\title{
Development of requirements for a decision support system aimed at quality assessment of public services provided based on the ontological approach ${ }^{1}$
}

\author{
Liliya R. Chernyakhovskaya \\ Professor, Department of Technical Cybernetics \\ Ufa State Aviation Technical University \\ Address: 12, Karl Marx Street, Ufa, Republic of Bashkortostan, 450008, Russian Federation \\ E-mail: Irchern@yandex.ru
}

\author{
Albina F. Galiullina \\ Doctoral Student, Department of Technical Cybernetics \\ Ufa State Aviation Technical University \\ Address: 12, Karl Marx Street, Ufa, Republic of Bashkortostan, 450008, Russian Federation \\ E-mail: GAF1205@yandex.ru
}

\begin{abstract}
This article describes the requirements for a decision support system which is designed to assess the quality of public services. Requirements for a decision support system are used as a starting point at its design stage and determine the functions of the developed system without showing the mechanism of its implementation. At the same time, the requirements serve as constraints in the process of system development. The set of the developed requirements for the decision support system includes basic, functional, non-functional and economic requirements.

We propose to use the ontological approach in the development of requirements for the system. This allows us to solve a number of problems arising from the description of the requirements in natural language: the lack of exposition clarity, misrepresentation of the requirements and so on. The ontological model allows developers to interpret the requirements in the same way, to structure the specification of requirements for the system and to eliminate blurring in their definitions. Ontological representation of knowledge about requirements for the developed system and about the system providing public services in general is used for the semantic integration of existing information resources, appropriate interpretation of the content of text documents and search queries presented in a natural language. The developed ontology improves the quality of user (stakeholder) interaction during the system operation. In addition, it includes rules for term combination to provide reliable assertions on the state of the decision support system.
\end{abstract}

Key words: decision support system, system of providing public services, basic requirements, functional requirements, non-functional requirements, economic requirements, quality assessment of public services provided, ontological model for decision support.

Citation: Chernyakhovskaya L.R., Galiullina A.F. (2017) Development of requirements for a decision support system aimed at quality assessment of public services provided based on the ontological approach.

Business Informatics, no. 1 (39), pp. 36-47. DOI: 10.17323/1998-0663.2017.1.36.47.

\footnotetext{
${ }^{1}$ This work was supported by the Russian Foundation for Basic Research, project no. 14-08-97023 "Intellectual support of managing decision-making in innovative projects relying on knowledge processing and mathematical modeling"
} 


\section{Introduction}

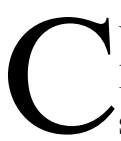
urrently in the Russian Federation issues related to the quality of services provided by the state have particular relevance and social significance. Organizations providing public services represent a queuing system that serves for the interaction of the country's population with state authorities, and this system should guarantee the maximum satisfaction of the citizens' needs in public services. At the same time, in accordance with one of the main directions of the realization of the Information Society Development Strategy in the Russian Federation approved by the President of the Russian Federation on 7 February 2008, it is necessary to improve the quality and responsiveness of the public services provided, including through e-government and the transfer of public services to electronic form. By the Decree of the President of the Russian Federation dated 7 May 2012 No. 601 "About the main directions for improving the system of public administration" it was determined that by 2018 the Russian Federation citizens' satisfaction level with the quality of public and municipal services provided should be at least $90 \%$.

Despite the relevance of solving the problem of improving the quality of public services, there is still no single methodology for their comprehensive assessment. There are various methods given in this article which are based on various indicators and criteria to assess the quality of public services. To date, a systematic approach to the analysis and quality assessment of the services is needed. The process of assessing provision of public services requires decision support in problem situations based on application of scientific approaches, namely, knowledge engineering and the ontological approach.

\section{Existing methods for assessing the quality of public services}

The works of such researchers as A. Parasuraman, V.A. Zeithaml, L.L. Berry, L. Gaster, G. Van Ryzin, S.I. Nedelko, A.V. Ostashkov, N.S. Mirzoyan, S.S. Tsukar, A.N. Lunev, N.B. Pugacheva, M.V. Koptev and others are devoted to assessment of service quality, including public services.

A. Parashuraman, V.A. Zeithaml and L.L. Berry proposed a method of assessing the quality of services SERVQUAL (abbreviated from "SERVice QUALity"), which involves measuring the service quality using a quantitative indicator - the service quality index SQI $[1,2]$. The service quality index SQI shows the ratio of the perceived and expected service quality. The SQI cal- culation is based on the results of the questioning service consumers. To measure customer expectations and perception of the quality of services received, two basic questionnaires are used. These include 22 pairs of questions grouped according to indicators of reliability, credibility, responsiveness, tangibility, sympathy. Questionnaires allow respondents to answer the questions using the seven-point Likert scale: from "absolutely disagree" to "absolutely agree". Note that the main problem of the results obtained through SERVQUAL questionnaires, and in particular the key indicator - the general quality index SQI - is the low degree of its informativeness. The index value itself can signal only the conformity of the assessed service to the quality or low quality category. The general index SQI rather reflects the average value, that is, a low score on one of the determinants can be compensated by a high score for another, while the general value SQI will be satisfactory. Thus, the development of specific recommendations requires a detailed analysis of the values of individual determinants, as well as the corresponding quality indices.

The SERVQUAL method was applied in the field of public services in the works of L. Gaster and G. Van Ryzin [3, 4]. The results of L. Gaster's study [3] showed that the lower social layers more often claim that they are satisfied with public services, while the more affluent often complain about the poor quality of public services. Social workers usually have higher expectations from social services, and therefore they think more critically and skeptically about the quality of services provided. As a result of the analysis of public satisfaction in the public services sector by G. Van Ryzin [5], it was revealed that respondents show a low degree of satisfaction with public sector services. The researcher explains this by the fact that the assessment of the public services' quality is based on public judgments about satisfaction with the authorities' activities.

To assess the public services, two groups of criteria are proposed by S.I. Nedelko and A.V. Ostashkov [6]:

1) the criteria for assessing the convenience (availability) of receiving the service: the consumer's awareness about receiving the service, the convenience of waiting for the service, the convenience of receiving the service, the availability of the service provided, the attitude of the staff to the consumer of the service, the possibility of appealing against actions by the personnel;

2) criteria for assessing the quality of the final result of the service: the time spent on receiving the final result of the service (quick response), the content quality of the final result of the service, staff competence. 
In addition to these two groups of criteria N.S. Mirzoyan [7] offers a third group - the amount of resources spent by the consumer to receive the service.

These criteria can be used as indicators for calculating the indices of satisfaction with the public services provided.

S.S. Tsukar [8] noted that in the development of services providing the public services, priorities are gradually shifting from traditional formats of providing services to modern electronic forms of interaction between government and society within the framework of the e-government concept. Together with the change of priorities, the structure of the criteria for quality assessment of the services provided is also changing. So, if in the traditional way that services are received by citizens the physical convenience of receiving services and personnel were important for them, then organizational barriers, problems of information perception and readiness for the use of new technologies play an important role in the electronic format of interaction. Therefore, the issues of assessing the quality of how public services are provided need to be approached differentially, taking into account the change in the weights of certain assessment criteria, i.e. the changed structure of quality criteria for providing the services in electronic form.

A.N. Lunev and N.B. Pugacheva [9] used the following basic criteria to assess the quality and availability of public services:

1) the level of public services quality characterized by the timeliness and speed of the services provided, compliance with the service standard, administrative regulations and service consumer requests $(\mathrm{Q} 1)$;

2) the level of public services availability, taking into account the convenience of waiting for and receiving the services, simplicity and rationality, contact and efficiency, openness and transparency $(\mathrm{Q} 2)$;

3 ) the level of consumer confidence in government authorities and their agencies providing public services (Q3).

The assessment of the quality and availability of public services is based on the value of the complex indicator $\mathrm{Q}=\mathrm{Q} 1+\mathrm{Q} 2+\mathrm{Q}$.

M.V. Koptev [10] noted that public service quality is characterized by the quality of the agency's internal processes and is ensured by the accurate operation of the operational accounting unit, the so-called "back office":

clear implementation of the administrative regulations of providing public services and compliance with legal norms and standards requirements;

$\checkmark$ qualified performance by public servants of their official regulations;

$\checkmark$ completeness, integrity, relevance and reliability of the information resources used;

using modern information and telecommunication technologies.

Assessment of the public services quality, according to M.V. Koptev, should be carried out directly by the applicants by an initiative order in specially developed questionnaires. It can be filed in multifunctional centers (MFCs), agencies providing services or on their websites, as well as through a public services portal where there is the possibility of filing a response. In addition, a project on public services assessment by means of sms messages has been launched and is being implemented.

As a result of the surveys conducted, a database is being formed analyzing the client experience of those who received the services. This base should form the basis for improving the entire system of providing public services in general and improve the work of the federal agency employees who provide public services, in particular.

However, despite all the changes made and available methods of quality assessment, the monitoring and assessment system of the public services quality is not fully debugged and needs to be improved.

\section{The need for decision support in assessment of the quality of public services}

State authorities, including federal agencies providing public services, like any modern organizational systems, operate in difficult conditions. Their viability depends on the ability to adapt their behavior to current and future environmental changes. Organizations need to mobilize information resources and apply knowledge engineering to ensure effective management of business processes, in particular, the process of providing public services and assessing the quality of this process. The problems of knowledge management in organizations are considered in the studies of many scientists [11-13].

Examples of corporate knowledge creation can be found in large Japanese, American, European companies such as Canon, Honda, Matsushita, Boeing, IBM, British Petroleum, etc., applying a holistic approach to knowledge management and adaptive behavior of the organization, as well as implementation of innovative projects based on new knowledge and ideas. 
In the management process, it is necessary to ensure compatibility of the concepts used, models and methods of knowledge management based on their formalization in order to improve the quality and quick response of management decisions. The following knowledge classes are defined in the organization: intuitive, implicit knowledge (heuristics, intuition, experience, skills), formalized, conceptual knowledge (mathematical models, rules for organizing effective actions), background, context knowledge (knowledge defining the cognitive context of activity conceptualization) [14]. Explicit knowledge is usually formalized in accordance with the accepted model of knowledge representation, for example, in the form of product rules and other formal models regulating processes management. Implicit knowledge for intellectual decision support is presented in the form of precedents of problem situations [15].

At present, the development of ontologies is proceeding actively, representing a clear conceptualization of subject areas and ensuring the interaction of the organization's specialists in solving complex problems in a single information space. Despite the development of the ontological analysis theory, as well as the development and application of new tools for creating ontologies, the integration problems of ontology and knowledge management remain insufficiently researched.

In order to ensure the required quality of the public services provided, it is necessary to conduct their assessment on an ongoing basis and make timely proper (correct) management decisions. To do this, it is necessary to apply scientific approaches (knowledge engineering) to decision support in problem situations arising when assessing the quality of providing public service. Decision support is a set of procedures that provides the decisionmaker with the necessary information and recommendations that facilitate the decision-making process.

Using the knowledge and experience of the organization, which are concentrated in standards, methods, administrative regulations and software applications, as source material for building a decision support system (DSS) will improve management efficiency and create the necessary information environment for the exchange of views and experience between specialists participating in the process of assessing the quality of public services.

Decision support systems are a relevant and developing field of information systems application for organizations [16].

The decision support system development for quality assessment of how public services are provided is implemented in accordance with the requirements submitted by various owners to the developed system at different stages of its life cycle. When requirements are forming, some contradictions may arise. Their reasons may be the different. In particular, such reasons include:

$\diamond$ different visions of consumer properties of DSS by various management subjects [17];

different assessments of problematic situations by various management subjects [18];

$\diamond$ the state of uncertainty of the external environment with regard to the control object $[19,20]$ and the internal environment of the control object [20,21], as well as a unique combination of internal and external environments [22];

$\diamond$ rejection by stakeholders of past commitments and unilateral violation of the agreements reached [20, 23].

The identification of contradictions at the early development stage is a critical success factor of the complex system management. Timely detection of contradictions and finding ways to resolve them prevent the appearance of difficulties. This makes it possible eventually to reduce the cost of DSS creation for assessing the quality of how public services are provided.

In addition, when DSS is being created, the experts often have complex problems, the cause of which is not always clear. In particular, it is difficult to describe the activities performed by the developed system clearly.

In connection with the above, authors offer to describe the functionality and limitations are imposed on the developed system, that is, requirements for DSS, complete and clearly.

As shown by many studies, mistakes made at the stage of gathering requirements constitute $40-50 \%$ of all defects found in the developed system $[24,25]$. The main causes of DSS development project failure are incorrect information from users and disadvantages of defining and managing user requirements [26].

Development of the requirements will make it possible to avoid more serious errors and problems at later stages of the DSS development for assessing the quality of how public services are provided.

\section{Requirements for a decision support system}

Development of the requirements for the DSS is a process involving activities that necessitate creating and approving the document stipulating the system requirements [27].

There are four main stages of the requirements development process for the DSS: 
1) feasibility study of the DSS development from a technical point of view;

2) formation and analysis of requirements for the DSS;

3) specifying requirements for the DSS;

4) relevant documentation development and certification of requirements for the DSS.

The chart of requirements for a decision support system developed by the authors is shown in Figure 1 .

The set of requirements for the DSS includes basic requirements, functional and non-functional requirements and economic requirements.

Basic requirements include the basic purpose of the developed decision support system and present highlevel generalized requirements. The DSS is being developed to form recommendations for decision-making, document decision-making, to ensure interaction between decision-makers and other stakeholders in the decision-making process, and to register the assessment of the decision support quality by the decision-maker or an expert.

Functional requirements cover expected behavior of DSS defining the actions that the system is able to perform. These requirements include decision support in the process of providing public services, registration of inconsistencies in quality of how public services are provided, description and analysis of the problem situation arising in assessing the quality of how public services are provided, search for solutions using rules and precedents of decision-making, ontological analysis, logging of citizens requests, the development and application of the knowledge base (KB), the development and regular updating of normative legal documentation database, event logging, etc.

Non-functional requirements are not directly related to the functions performed by the system. These requirements do not define the behavioral aspects of the system in the process of providing public services. They are associated with such integration properties of the system as the protection of confidential data, reliability, accuracy, communication, work in real time, access to the database and knowledge base, etc.

In particular, we note such non-functional requirement as speedy response. Responsiveness indicators are obtained using the decision support system as a queuing system (QS). QS has such indicators as the absolute, relative and nominal throughput, the number of QS channels, the idle factor and others.

Also it should be noted that many non-functional requirements apply to DSS on the whole and not to its in- dividual assets. Some non-functional requirements are more critical than individual functional requirements. If an error is made in the functional requirement, this can lead to a decrease in the quality of the developed system. If the error is made in non-functional requirements, for example, in the requirements of fault tolerance or controllability, then this can make the system completely inoperable.

Economic requirements imply an economic aspect is taken into account in the DSS development in the process of providing public services. It is necessary to assess the possible risks, the economic efficiency, the DSS realization cost and the time spent for realization and implementation of the DSS.

The system for providing public services must ensure conformity of the automated process of providing services to the requirements of normative legal acts including administrative regulations determining the order of providing public services by the executive bodies of state authority, federal agencies, local authorities and others.

\section{Application of the ontological approach to solving communication problems in the development of requirements for a decision support system}

In the class of decision support systems, intelligent decision support systems (IDSS) are allocated that are designed to help decision-makers manage complex objects and processes of various nature in the face of tight time constraints and the presence of uncertainty of various kinds (incompleteness, fuzziness and inconsistency of the original information, etc.). Such systems belong to the class of integrated intellectual systems that combine rigorous mathematical methods and solution search models with nonstrict, heuristic (logic-linguistic) models and methods based on the knowledge of experts, models of human reasoning and accumulated experience [28]. A distinctive feature of the tasks solved with the help of intelligent DSS is the impossibility of obtaining all the objective information necessary for decisionmaking, and in this connection - the use of subjective expert, poorly structured information. Highly qualified specialists of government bodies, federal agencies, state institutions, as well as experts engaged in scientific research in the field of knowledge management can be involved as experts.

The central component of IDSS is its knowledge base. The knowledge base is a set of information about the subject area organized in accordance with the accepted knowledge representation model. The knowledge base contains information relevant to a particular subject 


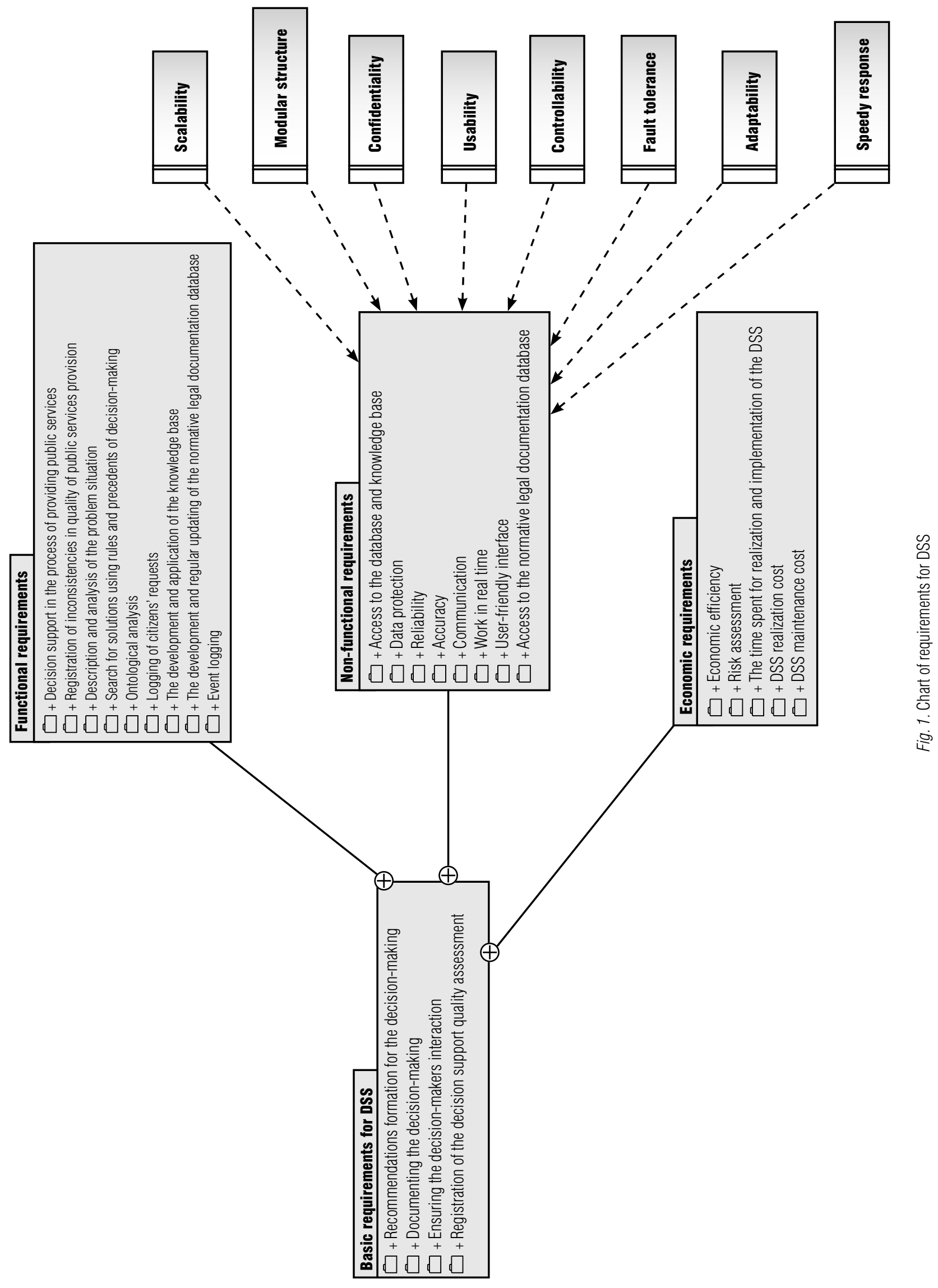


area: rules describing relationships and phenomena, individual facts, and also, possibly, methods, heuristic algorithms and various ideas related to decision-making in the relevant subject area [29].

One of the most important tasks in the development of DSS is the task of obtaining knowledge from a subject area expert and presenting it in the knowledge base of the IDSS.

The formalism of the knowledge description is called the knowledge representation model. There are various models of knowledge representation: ontology, logical model, product model, semantic network, frame model, precedents, dynamic model, etc.

Ontology is the explicit specification of conceptualization [30]. Formally, the ontology consists of terms organized in the taxonomy, their definitions and attributes, as well as the axioms associated with them and the rules of inference. In other words, ontology is knowledge formally presented on the basis of conceptualization, which involves the description of a multitude of objects and concepts, knowledge about them and the connections between them.

Ontology enhances the intelligence of knowledge management systems based on a representation of what often remains implicit or uncertain. Ontology solves the problem of sharing and reusing knowledge by various users and / or computer programs [31].

In each subject area, experts have their own specific scientific vocabulary (there is no single terminology). Some terms are used in several disciplines with similar but not identical meanings; there are synonyms, antonyms, homonyms. Therefore, it is extremely urgent to solve the problem of representing natural language information in a machine-interpreted form [32].

There is a need to develop a unified, detailed and consistent terminology that can be used in various formal contexts and applications. Ontology is a convenient way to create such terminology, taking into account the context of the subject area. Ontology takes into account the paradigmatic relations of concepts that are not dependent on the context of the problem solution, and the rules for the formation of syntagmatic relations concept variables arising in a certain context of the problem solution [33].

The approach based on ontologies is flexible enough and universal and has a number of advantages that justify its use in an environment with large volumes of information and the need to quickly extract its parts. As such, an environment is the decision support environment for assessment of the public services quality. This environment provides: collection of theoretical knowledge, its representation in the form of a semantic network of concepts and relations between concepts;

$\downarrow$ increasing the effectiveness of information searching based on the structuring and classification of stored knowledge;

$\checkmark$ the ability to collect, accumulate, process and present knowledge in the organization's Intranet network in accordance with the concept of "semantic web" [29].

When developing DSS, an approach is proposed based on the definition of requirements groups: functional, non-functional, economic, etc.

Some problems are arising during the requirements development due to the fact that there is no clear understanding of the differences between different levels of requirements. Requirements are commonly used as a means of communication between the different stakeholders. This means that the requirements should be simple and understandable for ordinary users of the decision support system and its developers, designers and others. In order to solve the problems arising, it is necessary clearly to distinguish the requirements of different levels and to determine the interpretation of the term of one requirement or another.

Specifications of DSS requirements are written in natural language and this often leads to certain problems when the detailed specification is written. The use of natural language implies that the same words and expressions in the requirements formulation are understood in the same way by stakeholders. However, in fact, this is not the case, since natural language has a certain blurring of concepts. As a consequence, the same requirement formulated by different specialists can be interpreted in different ways.

To avoid these problems and for unambiguous interpretation of the terms of the subject area (and, accordingly, the requirements for DSS developed for assessing quality of how public services are provided), we propose to develop the ontological model. This ontological model allows us to solve the problem of communication, structure requirements specification for DSS and eliminate blur of definitions. Thus, an approach is proposed to for intellectual decision support for assessment of the quality of how public services are provided based on the ontological knowledge base.

Using the ontological approach allows us to carry out an ontological analysis of the public services provision system and enables us to formulate the requirements for DSS designed to assess the effectiveness of how public services are provided. 


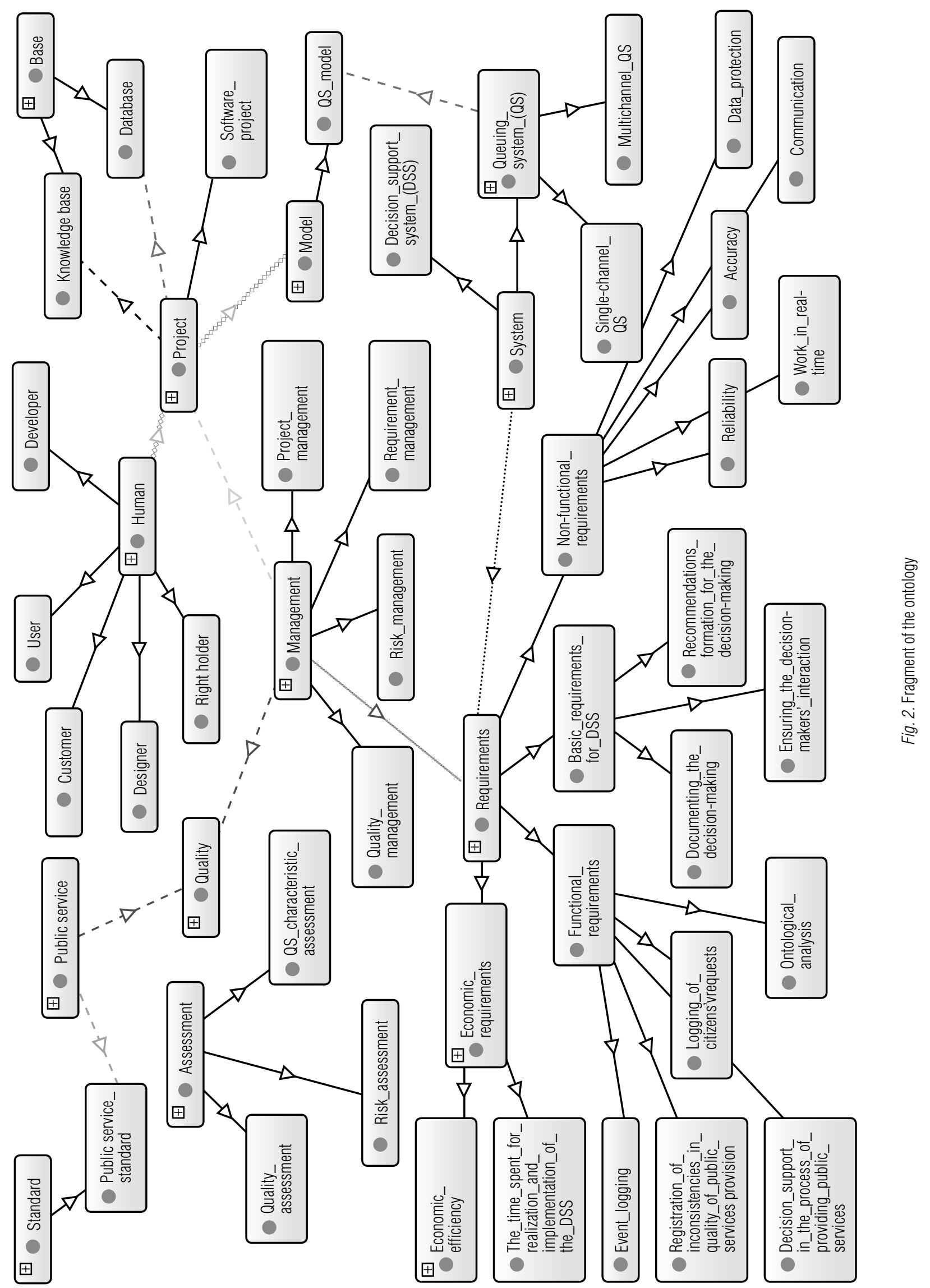


The advantage of using the ontological model is that it allows us to develop a metadata model. This greatly improves the interaction of a wide range of DSS users. Ontology enables us to provide the collective use of an understanding of the information structure by experts, state institutions employees, to re-use knowledge of the subject area as well as to analyze this knowledge.

The general concepts of the subject area, queuing systems and project management of DSS creation (based on a dictionary of software projects [34]) are included in the developed ontology as classes. Also, the developed ontology includes a hierarchy of requirements for DSS. Moreover, each term in the ontology has a straightforward interpretation. A fragment of the developed ontology is shown in Figure 2.

The developed ontology can be formally represented as [15]:

Onto $=<C, R, \operatorname{Pr}, V, I, A, D>$,

where $C$ - a set of classes $\left\{C_{1}, C_{2}, \ldots, C_{n}\right\}$;

$R$ - a set of relations $\left\{R_{1}, R_{2}, \ldots, R_{n}\right\}$;

$\mathrm{Pr}$ - properties of classes;

$V$ - values of properties: there is a division of properties into two classes in OWL: the object properties (instances of the class owl: ObjectProperty) and the properties of the data types (instances of the class owl: DatatypeProperty);

$I$ - a set of class instances $\left\{I_{1}, I_{2}, \ldots, I_{n}\right\}$ is determined by axioms and definitions of specific class properties;

$A$ - a set of axioms $\left\{A_{1}, \mathrm{~A}_{2}, \ldots, A_{n}\right\}$;

$D$ - a set of output algorithms at ontology $\left\{D_{1}, D_{2}, \ldots\right.$, $\left.D_{n}\right\}$

To find the necessary information in the developed ontology, a special request can be implemented by a specialist or other interested person. Through a request, any specialist involved in the development of a DSS for assessing the quality of public services provided (or another interested person) can find all the necessary information about the requirements for DSS by means of the developed ontology: find out which groups of requirements are relevant to DSS, and details of these requirements. Since the ontology contains the terms of the subject area, DSS users can form their requests for the developed ontology.

In addition to the terms, the ontology includes the rules according to which these terms can be combined to construct credible allegations about the state of the system at some moment in time. In addition, it may make appropriate conclusions based on these statements. These conclusions allow us to make changes in the system of how public services are provided to improve the quality.

\section{Conclusion}

The requirements development process for a decision support system to assess the quality of how public services are provided is very complicated and important, since errors in the requirements can lead to high costs for the development of the whole system.

A chart of the requirements for the DSS developed by the authors to assess the quality of how public services are provided is presented in this article. In addition, in this article they present an ontological model facilitating the interaction of the various stakeholders (users, developers and others) and allowing us to structure the specification of the requirements for the system.

\section{References}

1. Parasuraman A., Zeithaml V.A., Berry L.L. (1988) SERVQUAL: A multiple-item scale for measuring consumer perceptions of service quality. Journal of Retailing, vol. 64, no. 1, pp. 12-40.

2. Zeithaml V.A., Berry L.L., Parasuraman A. (1988) Communication and control processes in the delivery of service quality. Journal of Marketing, vol. 52, no. 2, pp. 35-48.

3. Gaster L., Squire A. (2003) Providing quality in the public sector: A practical approach to improving public services. Maidenhead, UK: Open University Press.

4. Van Ryzin G.G. (2004) The measurement of overall citizen satisfaction. Public Performance and Management Review, no. 273, pp. 9-28.

5. Van Ryzin G.G., Muzzio D., Immerwahr S., Gulick L., Martinez E. (2004) Drivers and consequences of citizen satisfaction: An application of the American customer satisfaction index model to New York City. Public Administration Review, vol. 64, no. 3, pp. $286-296$.

6. Nedelko S.I., Ostashkov A.V. (2008) Monitoring gosudarstvennykh i munitsipal'nykh uslug v regione kak strategicheskiy instrument povysheniya kachestva regional'nogo upravleniya: opyt, problemy, rekomendatsii [Monitoring of public and municipal services in the region as a strategic tool to improve the quality of regional governance: experience, problems, recommendations]. Moscow: Exlibris-Press (in Russian).

7. Mirzoyan N.S. (2010) Otsenka kachestva predostavleniya gosudarstvennykh (munitsipal'nykh) uslug [Quality assessment of public (municipal) services providing]. Tidings of the Tula State University. Economic and Legal Sciences, no. 2-2, pp. $217-223$ (in Russian).

8. Zucar S.S. (2014) Osobennosti otsenki kachestva predostavleniya gosudarstvennykh uslug v elektronnoy forme [Peculiarities of evaluation of quality of rendering state services in electronic form]. Management Consulting, no. 10 (70), pp. 137-144 (in Russian). 
9. Lunev A.N., Pugacheva N.B. (2013) Nauchno-metodicheskie rekomendatsii po otsenke kachestva i dostupnosti gosudarstvennykh i munitsipal'nykh uslug [Scientific and methodical recommendations on the assessment of the quality and accessibility of public and municipal services]. Society: Politics, Economics, Law, no. 4, pp. 15-27 (in Russian).

10. Koptev M.V. (2014) Otsenka kachestva predostavleniya gosudarstvennykh uslug v elektronnom vide [Estimating quality of public services provided in electronic form]. Problems of Modern Science and Education, no. 7, pp. 117-119 (in Russian).

11. Nonaka I. (1991) The knowledge-creating company. Harvard Business Review, vol. 69, no. 6, pp. 96-104.

12. Choo C.W., Auster E. (1993) Scanning the business environment: Acquisition and use of information by managers. Annual Review of Information Science and Technology, M.E. Williams (ed.). Medford, NJ: Learned Information, pp. 279-314.

13. Gavrilova T.A., Muromtsev D.I. (2008) Intellektual'nye tekhnologii v menedzhmente [Intellectual technologies in management]. St. Petersburg: Higher School of Management, St. Petersburg University (in Russian).

14. Vagin V.N., Pospelov D.A., eds. (2008) Dostovernyy i pravdopodobnyy vyvod v intellektual'nykh sistemakh [Reliable and plausible inference in intelligent systems]. Moscow: FIZMATLIT (in Russian).

15. Chernyakhovskaya L.R. (2010) Podderzhka prinyatiya resheniy pri strategicheskom upravlenii predpriyatiem na osnove inzhenerii znaniy [Decision support in strategic enterprise management based on knowledge engineering]. Ufa: ANRB, Gilem (in Russian).

16. Vostrov G.N., Mezhuev V.I. (2008) Problemy postroeniya informatsionnykh sistem nad predmetnymi oblastyami [Problems of construction of information systems on subject areas]. Artificial Intelligence, no. 4, pp. 736-746 (in Russian).

17. CIO (2011) Uchebnik 4CIO. Versiya 1.0 [Tutorial 4CIO. Version 1.0]. Moscow: 4CIO (in Russian).

18. Vittikh V.A. (2010) Organizatsiya slozhnykh system [Organization of complex systems]. Samara: Samara Scientific Center RAN (in Russian).

19. Lipaev V.V. (2005) Analiz i sokrashchenie riskov proektov slozhnykh programmnykh sredstv [Analysis and reduction of projects risks of complex software facilities]. Moscow: SINTEG (in Russian).

20. Rzevski G. (2014) Managing complexity. Proceedings of the 16th International Conference on Problems of Control and Modeling in Complex Systems, Samara, 30 June - 03 July 2014. pp. 3-12.

21. McConnel S. (2007) Skol'ko stoit programmnyy proekt [How much is the cost of a software project]. St. Petersburg: Piter (in Russian).

22. Gvozdev V.E., Ilyasov B.G. (2011) Piramida programmnogo proekta [Software project pyramid]. Software Engineering, no. 1, pp. 16-24 (in Russian).

23. Jordan E. (2008) Put'kamikadze [The path of the kamikaze]. Moscow: Lory (in Russian).

24. Davis A.M. (1993) Software requirements: Objects, functions, and states. Englewood Cliffs, NJ: Prentice Hall PTR.

25. Davis A.M. (1995) 201 principles of software development. NY: McGraw-Hill.

26. Wiegers K.E. (2004) Razrabotka trebovaniy k programmnomu obespecheniyu [Development of software requirements]. Moscow: Russian Edition (in Russian).

27. Klevtsov S.I. (2007) Analiz i formirovanie trebovaniy k PO informatsionnykh sistem sbora i obrabotki dannykh [Analysis and formation of requirements for information systems of data collection and processing]. Taganrog: TTI SFEDU (in Russian).

28. Korneev V.V., Gareev A.F., Vasyutin S.V., Raikh V.V. (2001) Bazy dannykh. Intellektualnaya obrabotka informacii [Database. Data mining]. Moscow: Knowledge (in Russian).

29. Paklin N.B., Oreshkov V.I. (2010) Biznes-analitika: ot dannykh $k$ znaniyam [Business intelligence: from data to knowledge]. St. Petersburg: Piter (in Russian).

30. Gruber T.R. (1993) A translation approach to portable ontology specifications. Knowledge Acquisition, no. 5 (2), pp. $199-220$.

31. Shkundina R.A. (2005) Organizatsiya podderzhki prinyatiya resheniy na osnove pretsedentov s pomoshch'yu ontologii predmetnoy oblasti [Organization of decision-making support on the basis of precedents with the help of domain ontology]. Proceedings of 3rd Conference on Artificial Intelligence in the XXI Century. Penza, pp. 70-72 (in Russian).

32. Filippovich Yu.N., Prokhorov A.V. (2002) Semantika informatsionnykh tekhnologiy: Opyty slovarno-tezaurusnogo opisaniya [Semantics of information technologies: Experience of dictionary and thesaurus description]. Moscow: MGUP (in Russian).

33. Smirnov S.V. (2001) Ontologicheskiy analiz predmetnykh oblastey modelirovaniya [Ontological analysis of modeling subject areas]. Tidings of Samara Scientific Center of RAS, vol. 3, no. 1, pp. 62-70 (in Russian).

34. Gvozdev V.E., Bezhaeva O.Ya., Tanzaly G.I., Efremova O.I. (2011) Programmnye proekty: bazovye terminy i opredeleniya [Software projects: basic terms and definitions]. Ufa: USATU (in Russian). 


\section{Разработка требований к системе поддержки принятия решений для оценки качества предоставления государственных услуг с применением онтологического подхода ${ }^{2}$}

\section{Л.Р. Черняховская}

доктор технических наук, профессор кафедры технической кибернетики Уфимский государственный авиационный технический университет Адрес: 450008, Республика Башкортостан, г. Уфа, ул. К. Маркса, д. 12 E-mail:Irchern@yandex.ru

\section{А.Ф. Галиуллина}

аспирант кафедры технической кибернетики

Уфимский государственный авиационный технический университет

Адрес: 450008, Республика Башкортостан, г. Уфа, ул. К. Маркса, д. 12

E-mail: GAF1205@yandex.ru

\section{Аннотация}

В статье представлено описание требований к системе поддержки принятия решений, которая предназначена для оценки качества предоставления государственных услуг. Требования к системе поддержки принятия решений используются в качестве отправной точки на этапе ее проектирования и определяют, что должна делать разрабатываемая система, не показывая при этом механизма ее реализации. Требования также служат ограничениями в процессе разработки системы. Совокупность разработанных требований к системе поддержки принятия решений включает основные, функциональные, нефункциональные и экономические требования.

Предлагается применение онтологического подхода при разработке требований к системе. Это позволяет решить ряд проблем, возникающих при описании требований на естественном языке: отсутствия четкости изложения, смешения требований, объединения требований и др. Разработанная онтологическая модель позволяет однозначно толковать требования к системе поддержки принятия решений для оценки качества предоставления государственных услуг, структурировать спецификацию требований к системе и исключить размытость их определений. Онтологическое представление знаний о требованиях к разрабатываемой системе и о системе предоставления государственных услуг в целом используется для семантической интеграции имеющихся информационных ресурсов, а также для адекватной интерпретации содержания текстовых документов и поисковых запросов, которые представлены на естественном языке. Разработанная онтология улучшает понимание и использование системы всеми заинтересованными лицами с точки зрения организации их взаимодействия. Разработанная онтологическая модель также включает правила, согласно которым термины скомбинированы для построения достоверных утверждений о системе поддержки принятия решений.

Ключевые слова: система поддержки принятия решений, система предоставления государственных услуг, основные требования, функциональные требования, нефункциональные требования, экономические требования, оценка качества предоставления государственных услуг, онтологическая модель поддержки принятия решений.

Цитирование: Chernyakhovskaya L.R., Galiullina A.F. Development of requirements for a decision support system aimed at quality assessment of public services provided based on the ontological approach // Business Informatics. 2017. No. 1 (39). P. 36-47. DOI: 10.17323/1998-0663.2017.1.36.47.

\footnotetext{
2 Работа выполнена при поддержке Российского фонда фундаментальных исследований, проект № 14-08-97023 «Интеллектуальная поддержка принятия решений при управлении инновационными проектами на основе обработки знаний и математического моделирования»
} 


\section{Литература}

1. Parasuraman A., Zeithaml V.A., Berry L.L. SERVQUAL: A multiple-item scale for measuring consumer perceptions of service quality // Journal of Retailing. 1988. Vol. 64. No. 1. P. 12-40.

2. Zeithaml V.A., Berry L.L., Parasuraman A. Communication and control processes in the delivery of service quality // Journal of Marketing. 1988. Vol. 52. No. 2. P. 35-48.

3. Gaster L., Squire A. Providing quality in the public sector: A practical approach to improving public services. Maidenhead, UK: Open University Press, 2003.

4. Van Ryzin G.G. The measurement of overall citizen satisfaction // Public Performance and Management Review. 2004. No. 273. P. 9-28.

5. Drivers and consequences of citizen satisfaction: An application of the American customer satisfaction index model to New York City / G.G. Van Ryzin [et al.] // Public Administration Review. 2004. Vol. 64. No. 3. P. 286-296.

6. Неделько С.И., Осташков А.В. Мониторинг государственных и муниципальных услуг в регионе как стратегический инструмент повышения качества регионального управления: опыт, проблемы, рекомендации. М.: Экслибрис-Пресс, 2008.

7. Мирзоян Н.С. Оценка качества предоставления государственных (муниципальных) услуг // Известия Тульского государственного университета. Экономические и юридические науки. 2010. № 2-2. С. 217-223.

8. Цукарь С.С. Особенности оценки качества предоставления государственных услуг в электронной форме // Управленческое консультирование. 2014. № 10 (70). С. 137-144.

9. Лунев А.Н., Пугачева Н.Б. Научно-методические рекомендации по оценке качества и доступности государственных и муниципальных услуг // Общество: политика, экономика, право. 2013. № 4. С. 15-27.

10. Коптев М.В. Оценка качества предоставления государственных услуг в электронном виде // Проблемы современной науки и образования. 2014. № 7. С. 117-119.

11. Nonaka I. The knowledge-creating company // Harvard Business Review. 1991. Vol. 69. No. 6. P. 96-104.

12. Choo C.W., Auster E. Scanning the business environment: Acquisition and use of information by managers // Annual Review of Information Science and Technology / M.E. Williams (Ed.). Medford, NJ: Learned Information, 1993. P. 279-314.

13. Гаврилова Т.А., Муромцев Д.И. Интеллектуальные технологии в менеджменте. СПб: Высшая школа менеджмента, СПбГУ, 2008.

14. Достоверный и правдоподобный вывод в интеллектуальных системах / Под ред. В.Н. Вагина, Д.А. Поспелова. М.: ФИЗМАТЛИТ, 2008.

15. Черняховская Л.Р. Поддержка принятия решений при стратегическом управлении предприятием на основе инженерии знаний. Уфа: АНРБ, Гилем, 2010

16. Востров Г.Н., Межуев В.И. Проблемы построения информационных систем над предметными областями // Искусственный интеллект. 2008. № 4. С. 736-746.

17. Учебник 4СІО. Версия 1.0. М.: 4СІО, 2011.

18. Виттих В.А. Организация сложных систем. Самара: Самарский научный центр РАН, 2010.

19. Липаев В.В. Анализ и сокращение рисков проектов сложных программных средств. М.: СИНТЕГ, 2004.

20. Rzevski G. Managing complexity // Труды XVI Международной конференции «Проблемы управления и моделирования в сложных системах». Самара, 30 июня - 03 июля 2014 г. С. 3-12.

21. Макконнел С. Сколько стоит программный проект. СПб: Питер, 2007.

22. Гвоздев В.Е., Ильясов Б.Г. Пирамида программного проекта // Программная инженерия. 2011. № 1. С. 16-24.

23. Йордон Э. Путь камикадзе. М.: Лори, 2008.

24. Davis A.M. Software requirements: Objects, functions, and states. Englewood Cliffs, NJ: Prentice Hall PTR, 1993.

25. Davis A.M. 201 principles of software development. NY: McGraw-Hill, 1995.

26. Вигерс К.И. Разработка требований к программному обеспечению / Пер. с англ. М: Русская редакция, 2004.

27. Клевцов С.И. Анализ и формирование требований к ПО информационных систем сбора и обработки данных. Таганрог: ТТИ ЮФУ, 2007.

28. Базы данных. Интеллектуальная обработка информации / В.В. Корнеев и [др.]. М.: Нолидж, 2001.

29. Паклин Н.Б., Орешков В.И. Бизнес-аналитика: от данных к знаниям. СПб: Питер, 2010.

30. Gruber T.R. A translation approach to portable ontology specifications // Knowledge Acquisition. 1993. No. 5 (2). P. $199-220$.

31. Шкундина P.A. Организация поддержки принятия решений на основе прецедентов с помощью онтологии предметной области // Сб. трудов III Всероссийской научно-технической конференции «Искусственный интеллект в XXI веке». Пенза, 2005. C. 70-72.

32. Филиппович Ю.Н., Прохоров А.В. Семантика информационных технологий: Опыты словарно-тезаурусного описания. М.: МГУП, 2002.

33. Смирнов С.В. Онтологический анализ предметных областей моделирования // Известия Самарского научного центра РАН. 2001. T. 3. № 1. C. $62-70$.

34. Программные проекты: базовые термины и определения / В.Е. Гвоздев и [др.]. Уфа: УГАТУ, 2011. 